\title{
Lumen
}

Selected Proceedings from the Canadian Society for Eighteenth-Century Studies

\section{Sarah Harriet Burney: Traits of Nature and Families}

\section{Lorna J. Clark}

Volume 19, 2000

Material Productions \& Cultural Construction

Culture matérielle \& Constructions discursives

URI : https://id.erudit.org/iderudit/1012320ar

DOI : https://doi.org/10.7202/1012320ar

Aller au sommaire du numéro

Éditeur(s)

Canadian Society for Eighteenth-Century Studies / Société canadienne d'étude du dix-huitième siècle

ISSN

1209-3696 (imprimé)

1927-8284 (numérique)

Découvrir la revue

Citer cet article

Clark, L. J. (2000). Sarah Harriet Burney: Traits of Nature and Families. Lumen, 19, 121-134. https://doi.org/10.7202/1012320ar

Copyright (C Canadian Society for Eighteenth-Century Studies / Sociéte canadienne d'étude du dix-huitième siècle, 2000
Ce document est protégé par la loi sur le droit d'auteur. L'utilisation des services d'Érudit (y compris la reproduction) est assujettie à sa politique d'utilisation que vous pouvez consulter en ligne.

https://apropos.erudit.org/fr/usagers/politique-dutilisation/ 


\section{Sarah Harriet Burney: Traits of Nature and Families}

Don't you find considerable merit in her novel, particularly in the conversations? The opening is embarrassed \& incorrect, but she afterwards gets on very well. \& I think the scene at the Emigrant Cottage really touching - at least it drew tears from $m e$, when I was not so prone to shed them, as at present. ${ }^{1}$

These words Charles Burney wrote to his daughter, Frances, on the publication of the first novel of Frances' half-sister, Sarah Harriet Burney. The timing is significant. Clarentine came out in three volumes in July 1796 almost simultaneously with Mme d'Arblay's Camilla, ${ }^{2}$ in whose praise Charles Burney waxed enthusiastic (as 'his most ardent passion'). ${ }^{3}$ He actively promoted the work of his elder daughter, Frances, 'with all the partial fondness of an old Grandfather ${ }^{4}$ and for many months relayed to her favourable opinions gathered among his acquaintance, defending her work fiercely against any criticism ('I never felt so zealous for the defence of any of her writings'). His involvement extended to trying to ensure favourable reviews by friendly voices (i.e. Burney family members). ${ }^{5}$

By contrast, it was left to Sarah's maternal aunt to propose finding her a friendly reviewer, an offer which was proudly refused. ${ }^{6}$ It was six months after publication that Charles Burney offered the brief comment cited above, the thrust of which is complicated by the fact that the scene he describes is actually a fictional rendering of the d'Arblays' own situation: a 'Mme d'Arzele' living in rural seclusion with a penniless French aristocrat who has fled the revolution. These idealised characters, noble and loving in the face of hardship, are those he recommends to his elder daughter as particularly moving.

On her part, Mme d'Arblay tried to be polite and encouraging to her younger sister-novelist, though clearly without taking her efforts too seriously. On a visit to Windsor, she was 'surprised' to find the King 'had heard of "Clarentine"' though the emphasis of the conversation, as she records it, was all on her own story: 'he asked me, smilingly, some questions about it, \& if it were true, what he suspected, that my youngest sister had a mind to do as I had done, \& bring out a work in secret? ${ }^{8}$ Here 
the strict veracity of Frances' account is open to question - she may be exaggerating the importance of her own role. ${ }^{9}$

This undervaluation, the 'privileging' of the elder sister's narrative within the family structure, is echoed in contemporary reviews which discovered in Sarah Harriet's novels 'a family likeness ${ }^{10}$ or attributed their merits to the author's belonging to a 'distinguished' literary family. ${ }^{11}$ Often the comparison is to their detriment; although 'there is a something in the ease and elegance of it, that speaks of the Burney, ${ }^{\prime 2}$ her work is declared inferior - to Evelina and Cecilia at least. The lustre of the Burney name, used openly after her second novel to promote her work, could be a two-edged sword when the 'family-talents' together with the 'family-likeness' led to charges of imitation. ${ }^{13}$ Resemblances of character were discovered as 'old acquaintances only in different situation ${ }^{\prime 14}$ and her novels represented as inferior copies of old favourites. The reviewer of her final work sums up the younger sister as 'quite as talkative, but by no means so well worth listening to. ${ }^{15}$

Yet her literary achievement is not inconsiderable: five works betweeen 1796 and 1839 which sold well, one of which was a bestseller, several of which ran to second editions, were translated into French and German, and pirated abroad. Some readers openly preferred the younger 'Miss Burney's' works, one of which inspired a sonnet written by Charles Lamb. ${ }^{16}$

Sarah Harriet Burney's work and personality were overshadowed not only at the time but also since by scholars who are biographers or critics of either Charles or Frances (or rather, Charles through Frances, since all his private papers passed through her hands and she was herself his first biographer). Daughter of the second marriage of Charles Burney with a wealthy widow, Elizabeth Allen, she 'developed' (Joyce Hemlow claims) 'what would now be called personality problems. For many years she was known as "poor Sal", Mrs. Burney's "poor little neglected Girl, Sally", half-ruined already, it was feared, in temper and manners, though everyone felt that she was improving or would soon begin to improve. ${ }^{17}$ But this perspective is based on criticism voiced by Frances or her correspondents who echo her disparagement of her half-sister's character and may be tainted to some degree by sibling rivalry.

Context is significant, as many of Frances' critical remarks appear in letters discussing her step-mother's death which occurred three years after her own marriage. The demise of the hated stepmother is hailed as a relief which will result in the improvement of Sarah Harriet's character and the release of Charles Burney's 'affections long pent or restrained' to flow again towards 'his Children' ('It is now,' she assures her husband, 'my own Ami will know that Father'). ${ }^{18}$ This release, restoring the home and family to their natural state (as she sees it) comes too late for her. She 
longs to 'return to him [her father] — for my whole heart yearns to devote itself to him ${ }^{\prime 19}$ but she is prevented by marital and maternal responsiblities. It is not surprising, therefore, that the daughter left in that envied position, usurping her desired role, should be judged as unequal to the task; her younger sister could never be seen as an adequate replacement for herself.

Similarly, Frances underestimated and misrepresented her father's feelings for her step-mother (confusing them perhaps with her own). Believing that his 'unmixed adoration' was reserved for 'our Mother' alone, she denied he would feel much grief at the death of his second wife, 'so much was previously gone of happiness in the Union. ${ }^{20}$ But Charles Burney's letters tell a different story, expressing both genuine love and inconsolable grief for the 'bosom friend \& rational companion of 30 years,' who had made his home 'not only desirable, but preferable' to any other place. ${ }^{21} \mathrm{He}$ was paralysed by depression for months afterwards - which surprised Mme d'Arblay although she still insisted that 'deep sorrow is impossible. ${ }^{22}$ But deep sorrow is expressed in Charles Burney's letters which describe the pain of bereavement as greater than he has ever felt before, even after the death of his first wife. ${ }^{23}$ The limitations of the viewpoint of Frances Burney are most obvious where her stepmother - or stepmother's daughter - is concerned.

The point is worth stressing when so respected a critic as Margaret Doody has recently claimed that Sarah Harriet wished to join her father's 'first and more real family - to be, in Maria's striking phrase, "one of his primitive Children." ${ }^{24}$ It is misleading to read Maria (Allen) Rishton's remark as giving precedence to the children of the first marriage; she is in fact distinguishing herself, a step-daughter by marriage alone, from Charles Burney's birth-children. Charles Burney's first marriage lasted eleven years, the second almost thirty; it is difficult in any case to imagine how one child can be more 'real' than another to its parent. These interpretations are symptomatic of the privileging of the text of one daughter over another, and of the distortions which result from the dominance of a single and partial viewpoint on the family situation.

The family and Frances Burney's role in it is of importance in recent scholarship. Feminist critics have explored her relationship to a patriarchal culture, reading suppressed rage and rebellion in her fictional works. ${ }^{25}$ The part played in both her imaginative and literary life by her actual father is of relevance to these revisionist readings; it should therefore be of interest to examine the writings of another literary daughter who shares to some degree the same patriarchal culture. I say to some degree because Sarah Harriet's relationship to her father began on its most intimate footing when her siblings left home; she was with him to the end which came thirty years later. ${ }^{26}$ It was she, and not 
Frances, who fulfilled the traditional role of stay-at-home daughter; they shared almost a lifetime together as he aged (not always gracefully). The experience certainly marked her, as can be seen in representations of the father and the family in her public and private writings.

Before we proceed, we will first need to clear the ground of misconceptions. 'Incest, like some invoked demon, haunts the eighteenth century' (according to Margaret Doody) and 'hovers over the heads, not just of fictional characters. ${ }^{27}$ Sarah Harriet Burney has passed into literary history with the charge of sibling incest hovering over her head. The seeds were sown by Joyce Hemlow who used the term 'elopement' to refer to a five-year period when Sarah and her married half-brother James left their respective homes to set up house together. Although Hemlow drew back somewhat from the titillating suggestion, ${ }^{28}$ critics who came after were less hesitant, speculating on the existence of illegitimate children, the damaging effect on James' $\operatorname{son}^{29}$ and the Freudian significance of these actions. Doody sees it as a classic Oedipean conflict, James opposing and Sarah Harriet uniting with the father, in a gesture expressing repressed anger as well as desire - for affection, recognition and acceptance within the family group. The alleged sexual transgression is read as 'another version, rendered by another daughter, of the struggle that occupied Frances Burney and found expression (though not resolution)' in some of her works. ${ }^{30}$

I think that this is an over-reading of the situation; the charge of incest does not stand up to a sober investigation of the evidence, little of which (with the exception of one or two remarks, reported at second hand and immediately disavowed) would support it. I have argued the case at length elsewhere, ${ }^{31}$ here I would simply say that the reactions of none of the principals, their family circle or friends suggest guilt or complicity in such a heinous crime. No scandal ever attached itself to Sarah Harriet's name; the supposition would be incompatible with the whole tenor and circumstances of her life. An awareness of gender relations, of her own role as a confirmed spinster (and her chafing at that role) surfaces in her letters during her time with James, ${ }^{32}$ but no sense of shame, embarrassment or guilt.

Charles Burney's reaction to the situation is of interest. Initially conciliating, he invited his absconding daughter to visit and sent her some money (perhaps he, more than anyone, could account for her motives in leaving). When she persisted in her resistance, however, his own attitude hardened. But it was the contagion's threatening to spread which enraged him, when having deserted ('unnaturally abandonned') ${ }^{33}$ her own post, she tried to tempt away his servant with a promise of social equality in this strangely liberated household. ${ }^{34}$ This last treasonous act pushed Charles Burney beyond the point of forgiveness, but the issue was one 
of duty and obedience, not that of sexual deviance. Sarah Harriet's greatest fault was to seek her own happiness, to put her own needs first. It was a reversal of good order and government, a subversive act, like the French Revolution he so feared. In a household which revolved around his own comfort, the self-abnegation of a female relative was essential, and Sarah's true sin was dereliction of duty, subversion of the true feminine character.

Doody sees Charles' reaction as suppression, a comical lowering of the situation, ${ }^{35}$ but the letters of an aging Charles Burney show his growing self-absorption and his imperative need of a female to administer to his wants. Sarah Harriet was one of a long line which included two wives, four daughters, four grand-daughters, a niece and some servants, all of whom acted at various times as housekeeper, companion, secretary, librarian and 'amanuensis. ${ }^{36}$ Frances Burney thought this but natural: 'he cannot live without some female society' she insisted; her father needed 'a female of his family to attend him, as well as to bask in the sunshine of his kindness, ${ }^{37}$ as she put it. But anyone who resisted the call or who did not cater fully to his needs incurred Charles Burney's wrath, not only Sarah Harriet but even a servant who chose to marry. ${ }^{38}$

Ironically, if one divests oneself of the notion of incest and refrains from imposing the structure of romance, an even more interesting pattern emerges, one quite startling for the time. For in leaving the paternal home in a quest for personal happiness, Sarah Harriet Burney enacted bodily what is implicitly or subconsciously expressed in the fictional works of Mme d'Arblay. Stating confidently, 'I trust I am gone to be happy \& Comfortable, ${ }^{39}$ the younger Burney explicitly rejected her subservient role in a transgressive act of rebellious self-assertion. Her action showed a remarkable spirit of independence and courage - even a certain eccentricity ${ }^{40}$ - traits which are evident in both her letters and her life. ${ }^{41}$ In so doing, she incurred the wrath of her elder sister, who was scathing in criticisms of her behaviour, her unfeminine 'habit of exclusively consulting just what she likes best, ${ }^{42}$ highly censurable in a woman as showing a blamable 'wilfulness \& selfishness' of character. ${ }^{43}$ Her pride (she had a 'high Spirit') ${ }^{44}$ and boldness were blamable traits inherited from her mother, ${ }^{45}$ and caused problems in dealing with her father, creating 'a species of dissention to which he has little been accustomed in his daughters.' To Mme d'Arblay, Sarah Harriet inexplicably reversed the natural order of things: 'Sally will not consult his taste, \& he, of course, cannot think of conforming to her's. ${ }^{46}$

It is also revealing that her father's character would provide sufficient motivation for such drastic action, which suggests that reality was far indeed from the idealised portrait of genial paterfamilias presented in the Memoirs of Mme d'Arblay. Sarah Harriet's view of her father was 
different; she believed that 'nothing but Servile Flattery and Fear kept him in good humour' and 'complaind bitterly' of his treatment of her. ${ }^{47}$ On leaving him, she protested, 'it is no part of my Intention to be good-fornothing and deserve abuse,' as if she felt the need to defend herself. ${ }^{48}$ The tension in the household was observed by a witness who found it 'so Wretchedly uncomfortable' that she too wished to leave and dreaded remaining alone with Dr. Burney. ${ }^{49}$ ('I was never so happy as when I turnd my back' on the place. $)^{50}$ Those female relatives who had the difficult task of caring for the aging patriarch paint a dark picture which may be reflected in the conflict and violence contained in Mme d'Ar-

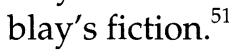

Emotional abuse is realistically rendered in a novel, Laura Valcheret, published anonymously by the orphaned grand-daughter, Frances Phillips, who eventually replaced Sarah Harriet in the paternal home. In her curious tale, several of the characters appear to be patterned after the Burney family. The heroine lives alone with an elderly father whom she displeases by neglecting her duties and accepting social engagements instead of staying home to tend to his needs. The strength of his disapproval appears out of proportion to her faults; in the chilling scenes which follow, she endures her father's unspoken disapproval and withdrawal of affection until her spirit of resistance is broken and she abases herself to win forgiveness. It is a convincing portrayal of emotional blackmail, which Sarah Harriet found deeply moving. ${ }^{52}$

Equally revealing in this regard is Sarah Harriet's third novel, Traits of Nature. She herself believed it to be her best. ${ }^{53}$ It was undoubtedly the most commercially successful, selling out within four months. ${ }^{54}$ For the first time, she published with the eminent firm of Henry Colburn, the 'principal publisher of novels and light literature' of the day ${ }^{55}$ and he paid her well for it $-£ 50$ a volume ${ }^{56}$ Curiously, although it clearly struck a chord with its largely female audience, the reviewers were less favourable and paid it no credence until its popularity compelled their notice. ${ }^{57}$

The title was suggested by Colburn and adopted against Sarah Harriet's wishes. ${ }^{58} \mathrm{~A}$ more fitting one might have been Traits of Families, as those depicted vividly evoke 'a Gothic nightmare, worse than anything in Frankenstein. ${ }^{159}$ The novel shows two hostile families who intermarry and eventually reconcile. Meanwhile, the domestic scenes of family life are truly horrific, exposing a seething hotbed of malice and aggression, daughters jockeying fiercely for position while sons, pampered and indulged, lord it over them freely. Fathers are tyrannical and cruel; the least destructive is a self-indulgent epicure, superficially charming provided nothing interferes with his gratification. Mothers grimly manipulate their daughters in the marriage market, the one sphere where they have influence. 
Against this backdrop, the heroine stands isolated, alienated and disregarded. Expelled from her father's home, Adela Cleveland lacks any status in society which only paternal sponsorship could give. The virtues she boasts are those which allow her to survive her exiled state and consist of negations. She is admired for her self-command, that is, she represses any show of emotion which would leave her vulnerable, any sign of weakness which could be exploited; for her self-denial, which becomes so habitual that she will scarcely allow herself to feel love even for the deserving hero; and for her self-abnegation - she denies feeling anger, never harbours ill-will, and makes no effort to assert her own rightful claims (this is done for her by her brother). In the action of the novel (which aims at her reinstatement in the paternal home), she is largely passive. The contest takes place between her brother and her father, and the former helps her in the end only when it serves his own self-interest. Although told of her beauty and gaiety (shown in dialogues of rather sharp repartee), the reader is left with the image of a pale, sad face as, 'Silent, abstracted, unamused, she slowly paraded through the magnificent apartments. ${ }^{60}$ At times, her painful loneliness in the midst of crowds (enduring 'wilful neglect, publicly manifested' [3: 20]) is the heaviest cross she has to bear. But her sense of isolation can be equally crushing in private:

The mere ceremony of assembling in the same room, and calling each other mother and daughter, cousin and brother, effects but little. Ease and intimacy are so far from being inseparably attached to nearness of kindred, that in the whole circle of creation, nothing can surpass the heaviness and restraint which is often seen ... pervading, "in clouded majesty," a family party. (3: 224)

The plot of the novel is familiar: a quest for acceptance and identity. The reasons for the heroine's outcast condition are also not new: Adela's mother, disgraced and divorced, has fled her husband's tyranny, and her infant daughter (though innocent) is rejected to punish her transgressions. The path back is complicated by her impetuous brother, who has never learned to restrain his passions and nurtures a violent hatred towards an otherwise unexceptionable hero, Lord Ennerdale, whose suit is initially rejected. This obstacle to the union is cleared when the brother providentially falls in love with the hero's sister and repents his fomenting of family prejudice.

Suspense in the novel does not depend on the central love interest, which is never greatly in doubt and comes to fruition somewhere between the lines. A scene of eclaircissement is repeatedly interrupted and deferred until finally both principals begin to act as though it had already occurred (the hero proceeding on 'presumptive evidence' of her attach- 
ment [4: 202]). Without ever having to declare her love, the self-controlled heroine can turn to what really matters - winning her father's approval.

At the nadir of her fortunes, the heroine's position is stark: 'My father, by appearing to disown me, casts a stigma upon my birth - my title to the name I bear is questioned - I have no appropriate rank in society I am a rejected, unvalued being who can bring into no family either honour, wealth, or even the negative advantage of an undisputed descent!' (4: 199). Her re-integration into society takes a whole volume but is not uncheckered. She is first reinstated in the family mansion though without the bathos, the tearful, erotically-charged scenes of father-daughter reunion which mark so many novels, Evelina, for instance. This long awaited moment is somewhat anticlimactic; her brother advises her simply to take up her role in medias res with as little fuss as possible: 'My dear Adela, put tenderness and fine feelings, on the present occasion, out of your thoughts! They are not dealt in at our house; and after all, as my father has nothing to forgive, or to found a pathetic scene upon, there appears the less necessity for an unwitnessed interview' (5: 42). Her reception is not a warm one. After having neglected her education for twenty years, Mr. Cleveland is favourably impressed with her poise and accomplishments but still finds a fault - neglect of her music - with which to berate her. He persecutes her with unreasonable demands for improvement to which Adela submits meekly for she yearns for affection, to win a place, not only in his house but in his heart. On her first night beneath her father's roof, 'Even the remembrance of Lord Ennerdale, for awhile, lost its distinctness; her father, almost exclusively, filled her thoughts. She reflected upon the rapture it would give her, to succeed in awakening an interest in his heart - to hear him own that she was becoming essential to his happiness' (5: 62).

Unfortunately, this aim is never achieved, although at one time Adela has hopes that her importance to him has increased, expressed again through a series of negatives. When her father falls sick, she nurses him tenderly:

He would acknowledge no pleasure in receiving her attentions: but the attentions of any other were not even permitted. At her, if he never smiled - at every one else he decidedly frowned. ... and though he seemed to disdain whatever she suggested, he did nothing without requiring her opinion. From these symptoms, ungracious as they were, she extracted hope sufficient to support her with courage through her task, and to flatter her, that as his health amended, she might reasonably look forward to amended days - days when she should not merely be tolerated, but loved. (5: 104-05) 
Within the confines of his shallow and imperfect character, however, their relationship progresses no further until the stumbling block to her marriage is suddenly removed (by outside events, of which she has been kept completely in the dark). Her lover's vows are now sanctioned by her father, who pompously blesses the union with a 'parading' ostentation which chills even the hero's ardour (5: 236). Since the suitor is a fantastically wealthy peer who will raise Adela to the rank of countess, there is not much heroism involved in his acquiescence.

But the real emotional climax occurs when, 'flying' to thank her father for his permission, Adela discovers - not that she has managed to win his love, but rather that she has developed some affection for him; to her surprise, she finds 'genuine feeling' in her expressions of gratitude. The narrator comments: 'Her father was in many respects wholly unamiable: but, not more wilfully blind was he to his own defects, than his daughter had scrupulously chosen to remain. The wish to love and revere him had been so persevering, that it had at length effected its own realization.' Her habits of stern self-denial have achieved this victory by subduing in herself any tendency to rebel or even to open her eyes to the truth. This 'virtuous propriety ... had obtained its meed, and tended to confirm those sentiments of filial veneration without which she could have known no happiness under the paternal roof' (5:235-36). She is now ready to take her place in the family and even enjoy what little it has to offer.

The emotional thrust of the ending is displaced onto the father-daughter relationship, but with a difference - what has been won is not so much acceptance of the daughter by the father, but rather the reverse. The meaning of the heroine's quest for a place in the patriarchy has been subverted. Traits of Nature is a novel of education, of coming-of-age; it depicts the entry of the heroine into the adult world, but it offers an interesting twist. Through a hard-won battle (with herself, primarily), Adela has faced and come to terms with the imperfections of her father, her family and society - having learned to live with these, she is now ready to accept her role in a patriarchal culture. But the emotional cost has been tremendous and the value of what has been achieved is also open to question.

The novel ends on a subdued note; it does not confer perfect felicity on a heroine who has long since given up such hopes as delusory. Undemonstrative and undemanding, Adela has learned to accept that 'there is no condition, whatever may be its allurements in perspective, to which, when attained, some draw-back is not annexed' (5: 66), which is all the affirmation the novel has to offer. The philosophy to which she subscribes (associated with La Rochefoucauld) expresses if not cynicism, at least despair over the evil heart of man. It is fraught with the anguish of one who has been hurt by the world and suffered the pain of disillu- 
sion. At one point, when Adela protests the need to accommodate herself to an imperfect world, she is admonished by her elder sister, a fount of maternal wisdom:

You shall have a little planet fitted up for yourself and a few beings formed expressly to reside with you in it. And it shall have an atmosphere of its own, through which every object shall distinctly appear such as it really is, without embellishment or deception of any kind. Meanwhile, condescend, in this terraqueous ball, to look through, and also sometimes to be seen through, a delusive medium. (3: 201-02)

In an imperfect world, one should cherish no unrealistic expectations.

The concluding marriage (which is never actually represented) is quickly absorbed into the family saga in which the characters are given their just deserts; Adela's disgraced mother becomes an alcoholic and dies young; a sister who married for money finds no happiness but 'unloving and unloved, she plodded on' through life, managing to avoid disgrace (5: 245); her tormenting cousin becomes a cripple but finds religion, while another remains 'wrapped up in self-consequence, ... [she] passed through a life of imaginary importance, with as little joy as sorrow, as few expectations or disappointments as ever fell to the lot of human being' (5: 248-49). This is the just mean intended in the ending of Cecilia, but with a bitter after-taste. When the newly married couple retires to their estate, one wonders just what has been achieved in the new order.

In some ways, the mood of this novel is more sombre than those of Mme d'Arblay. This Burney offers an even greater challenge to the patriarchy, by completely undercutting its value. The heroine who had yearned for her father's acceptance in the end finds it worth so little as hardly to warrant the cost. Yet while there is diminishment, there is at least acceptance, a healthy accommodation to the world as it is. Life offers little enough, but what little there is might as well be enjoyed. The real meaning of the quest is learning to live within limits; true feminine virtue consists in coming to terms with these and repressing all unavailing complaints. And if along the way one manages to create a small measure of joy and affection, then that is a real accomplishment. The novel closes with Adela installed at Mordington Castle, acting as 'the bond of union between her father and her lord' (5: 251), and surrounded, presumably, by an array of tormenting relatives. The last line celebrates her virtue in being the most 'unpresuming of human beings' (5: 251). This appears to be all the celebration of which the novel is capable.

There is a coda as well to the story of Sarah Harriet Burney. She too would return to the house of her father. In a scene taken straight from a 
novel, she appealed through her sister Esther's mediation for reconciliation, repenting 'her late rash \& undutiful desertion' and promising to make 'all the reparation in her power by her future cares \& attention on this score. ${ }^{61}$ She was allowed to move back home when Charles Burney was away and began the thankless task of caring for the peevish and self-absorbed octogenarian who thought only of his own 'convenience or interest. ${ }^{\prime 62}$ She found that he still required flattery and had to repress her 'wayward spirit' aroused by his petulance. ${ }^{63}$ She took to reading sermons to quell her spirit of rebellion and to reading anything as a substitute for sociable human contact (for her attendance could rarely be spared). She lived in fear of her father and often lacked the courage to ask permission to enjoy some outing - she found it easier to forgo such pleasures. ${ }^{64}$ As the end neared, she had ample opportunity to live the scenes described so vividly in the novel, of nursing a fretful invalid in the desperate hope of arousing some affection.

But when her father died in 1814 and the will was read, it appeared that all her efforts at expiation had been in vain. Charles Burney appears never to have forgiven his two undutiful children. He virtually disinherited James, the eldest son, and left little enough for Sarah Harriet (the one unmarried daughter), not nearly enough to live on ('One thousand Pounds and one hundred Pounds more for a wedding Garment if ever she marries, ${ }^{65}$ although she was by then past the marrying age). She was left far less than Frances d'Arblay and not even so much as one of her nieces. Moreover, Charles Burney failed to pass on some property left by her grandmother, in effect taking her maternal inheritance and distributing it unequally among the children of his first marriage. ${ }^{66}$ Sarah Harriet was left, like the heroine of one of her novels, impoverished, abandoned, rejected - and alone.

The story does not end there; there are more novels to consider and Burney had half a lifetime to live. But perhaps I have said enough to indicate a direction for further investigation. The novels of Sarah Harriet Burney deserve more attention which they will amply repay. They are of interest not only for the light they shed on her sister-novelists with whom they share common issues and concerns but also in and of themselves. There is much to learn from her struggle, its expression and the solutions which are offered.

LORNA J. CLARK

Ottawa 


\section{Notes}

1 Charles Burney to Frances (Burney) d'Arblay, 2 December 1796, Henry W. and Albert A. Berg Collection, New York Public Library, Astor, Lenox and Tilden Foundations.

2 The Letters of Sarah Harriet Burney, ed. Lorna J. Clark (Athens: U of Georgia P, 1997), 29 n2; The Journals and Letters of Fanny Burney (Madame d'Arblay), ed. Joyce Hemlow, vol 3 (Oxford: Clarendon, 1973), 168 n1.

3 Journals and Letters of Fanny Burney, 3, 239.

4 Charles Burney to Charles Burney Jr., [18 July 1796], copied in Susanna (Burney) Phillips to Frances (Burney) d'Arblay, published in R. Brimley Johnson, Fanny Burney and the Burneys (London: R. Stanley Paul, 1926), 223.

5 Charles Burney to Charles Burney Jr., 3 August [17]96, Bodleian, MS. Don. c. 56, ff. 87-8.

6 Letters of Sarah Harriet Burney, 28-29.

7 See, for example, [Sarah Harriet Burney], Clarentine (London: G. Wilkie and J. Robinson, 1796), 1, 121-31 \& 143-58.

8 Journals and Letters of Fanny Burney, 4, 19.

9 Frances' alteration of the manuscript in order to aggrandise her own role in Charles Burney's Memoirs is described in Roger Lonsdale, Dr. Charles Burney: A Literary Biography (Oxford: Clarendon, 1965), 432-55, especially 449-52.

10 Monthly Review, 2nd ser., 21 (1796): 452-56.

11 British Critic, 32 (1808): 520. Although her first two novels were published anonymously, their authorship appears to have been an open secret.

12 Critical Review, 3rd ser., 16 (1809): 104-05.

13 Monthly Review, 2nd ser., 71 (1813): 102-03.

14 Critical Review, 4th ser., 42 (1812): 519-27.

15 Athenaeum, no. 625 (19 Oct. 1839): 793.

16 Charles Lamb, 'Sonnet To Miss Burney, on her Character of Blanch in "Country Neighbours," a Tale,' Morning Chronicle, 13 July 1820; reprinted in The Works of Charles and Mary Lamb, ed. E.V. Lucas (London, 1903; reprint, New York: AMS Press, 1968), 5, 82-83.

17 Joyce Hemlow, The History of Fanny Burney (Oxford: Clarendon, 1958), 47.

18 Journals and Letters of Fanny Burney, 3, 219, $250 \& 212$.

19 Ibid., 3, 239.

20 Ibid., 3, 218.

21 Charles Burney to Ralph Griffiths, 2 November 1796, Bodleian, MS. Add. C. 89, ff. $1-2$.

22 Journals and Letters of Fanny Burney, 3, 239.

23 Charles Burney to [Dorothy Young], [c. 27-31 October 1796], James Marshall and Marie-Louise Osborn Collection, Beinecke Rare Book and Manuscript Library, Yale University. 
24 Margaret Anne Doody, Frances Burney: The Life in the Works (New Brunswick, NJ: Rutgers UP, 1988), 279. Maria (Allen) Rishton uses the phrase 'one of his primitive Children' in a letter to Frances (Burney) d'Arblay, 24 December 1796, British Library Egerton MS 3697, ff. 237r-v. Part of the letter is quoted in Doody, 278. Maria (Allen) Rishton was the daughter of the second Mrs. Burney's first marriage.

25 I refer to the tradition established in Doody and Julia Epstein, The Iron Pen: Frances Burney and the Politics of Women's Writing (Madison: U of Wisconsin P, 1989). A recent example is the Special Evelina Issue, Eighteenth-Century Fiction, vol. 3, no. 4 (July 1991).

26 Her siblings had left home for the most part after 1786, the year that Charlotte married and Frances was appointed to the household of the Queen. After Frances retired in July 1791 and before her marriage of July 1793, she spent most of her time travelling or on visits. See Hemlow, 194, 222-37 passim.

27 Doody, 277.

28 Hemlow, 281-85.

29 Winifred S. Courtney, 'New Light on the Lambs and Burneys,' Charles Lamb Bulletin, n.s., no. 57 (Jan. 1987): 19-27.

30 Doody, 277-81.

31 Clark, introduction to Letters of Sarah Harriet Burney, xxxvi-xlii. See also 33-44.

32 See e.g., Letters of Sarah Harriet Burney, 43.

33 Journals and Letters of Fanny Burney, 4, 216.

34 Charles Burney and Maria (Allen) Rishton to Frances (Burney) d'Arblay, 26 October 1798, Berg.

35 Doody, 282

36 The phrase occurs in several letters, e.g. Charles Burney to Samuel Wesley, 17 October 1808, Osborn.

37 Journals and Letters of Fanny Burney, 4, 275 \& 330.

38 Charles Burney protested strongly when his servant agreed to marry 'a scots-man, a presbiterian, a furious Jacobin and a Tyrant' and wished to 'emancipate' her: 'It distressed and vexed me very much' (Charles Burney, Fragmentary Memoirs, Berg). He later complained of the difficulty of training her successor (Charles Burney to Frances Crewe, [19 October 1803], Osborn).

39 Letters of Sarah Harriet Burney, 35.

40 Journals and Letters of Fanny Burney, 4, 97; Maria (Allen) Rishton to Frances (Burney) d'Arblay, [24 Dec. 1796], Barrett Collection, British Library, Eg. 3697, ff. $237-44 v$.

41 Clark, introduction, 1-li.

42 Journals and Letters of Fanny Burney, 3, 352.

43 Ibid., 4, 177.

44 Maria (Allen) Rishton to Frances (Burney) d'Arblay, [3 Sept. 1798], Barrett, Eg. 3697, ff. 276-77v. 
45 SHB lived in a 'perpetual State of Warfare' with her mother: ' - She was Violent and often took up things too warmly - and Certainly my poor Mother did irritate and try her temper to the Utmost' (Maria (Allen) Rishton to Frances (Burney) d'Arblay, [24 December 1796], Eg. 3697, ff. 237-44v).

46 Journals and Letters of Fanny Burney, 4, 177.

47 Maria (Allen) Rishton to Frances (Burney) d'Arblay, [3 September 1798], Barrett. Eg. 3697, ff. 276-77v.

48 Letters of Sarah Harriet Burney, 35.

49 Maria (Allen) Rishton to Frances (Burney) d'Arblay, [3 Sept. 1798], Barrett, Eg. 3697, ff. $276-77 \mathrm{v}$.

50 Maria (Allen) Rishton to Frances (Burney) d'Arblay, 5 September [1798], Barrett, Eg. 3697, ff. 278-79v.

51 Julia Epstein emphasised these elements in The Iron Pen.

52 Clark, introduction, xxxix-xl.

53 Letters of Sarah Harriet Burney, 149.

54 Letters of Sarah Harriet Burney, 151 n9; 159 n9.

55 'Appendix,' Annual Register, 97 (1855): 300.

56 Letters of Sarah Harriet Burney, 157

57 No reviews were published until after the second edition. See Critical Review, 4th ser., 42 (1812): 519-27; Monthly Review, 2nd ser., 71 (1813): 102-03; British Critic, 41 (1813): 643.

58 Letters of Sarah Harriet Burney, 157.

59 The phrase is used of the Harlowe family by James Grantham Turner, 'Richardson and His Circle,' in The Columbia History of the British Novel, ed. John Richetti (New York: Columbia UP, 1994), 97.

60 Sarah Harriet Burney, Traits of Nature (London: Henry Colburn, 1812), 3, 20. All further references to this work appear in the text.

61 Esther (Burney) Burney to Charles Burney Jr., 1 March 1806 [1807], Osborn.

62 Letters of Sarah Harriet Burney, 137.

63 Ibid., 145 \& 137.

64 Ibid., 114.

65 Charles Burney's will is transcribed in Percy A. Scholes, The Great Dr. Burney, vol. 2 (London: Oxford UP, 1948), 262-72.

66 Letters of Sarah Harriet Burney, 22 n2 \& 185 n2; see also Lorna J. Clark, "The Fortune of Elizabeth (Allen) Burney Reconsidered,' Notes and Queries, 240 (1995): 462-67. 